\author{
Selective laser melting 공정으로 제조된 AISI 316L 합금의 \\ 상온 및 고온 압축 변형 거동 \\ 함기수 ${ }^{1} \cdot$ 박순홍 ${ }^{2} \cdot$ 이기안 ${ }^{1 *}$ \\ 1 인하대학교 신소재공학과 \\ 포항산업과학연구원
}

\title{
Room and Elevated Temperature Compressive Deformation Behavior of AISI 316L Alloy Fabricated by Selective Laser Melting Process
}

\author{
Gi-Su Ham', Soon-Hong Park², and Kee-Ahn Lee ${ }^{1, *}$ \\ ${ }^{1}$ Department of Materials Science and Engineering, Inha University, Incheon 22212, Republic of Korea \\ ${ }^{2}$ Research Institute of Industrial Science \& Technology, Pohang 37673, Republic of Korea
}

\begin{abstract}
This study investigated the microstructure and compressive properties (at room \& high temperatures) of Fe-Cr-Ni based AISI 316L alloy, manufactured by selective laser melting process. The effect of stress relieving heat treatment on the microstructure and mechanical properties also examined. Regardless of the stress relieving heat treatment, the SLMed AISI 316L alloy exhibited typical molten pools and fine columnar structures which grew along the laser heat source. A cellular type dendrite structure was also observed inside the molten pool. After heat treatment, the low angle boundary fraction decreased and the high angle boundary fraction increased in the SLMed AISI $316 \mathrm{~L}$ alloy. In the $25^{\circ} \mathrm{C}, 500^{\circ} \mathrm{C}, 700{ }^{\circ} \mathrm{C}, 900^{\circ} \mathrm{C}$ compressive results, the heat treated $316 \mathrm{~L}$ alloy showed lower yield strengths than the as fabricated alloy at all temperature conditions. However, the difference in yield strength between the as fabricated and heat treated alloys gradually decreased with increasing temperature. Surface and cross-sectional fractographies showed that the heat treated alloy accommodated more plastic deformation. This was considered the cause of the more pronounced work hardening of the heat treated alloy, as identified in the stress versus strain curves. The correlations between microstructure, temperature dependent mechanical properties and stress relieving heat treatment were also discussed based on these findings.
\end{abstract}

(Received February 12, 2019; Accepted April 12, 2019)

Keywords: selective laser melting, AISI 316L, heat treatment, microstructure, compressive test, high temperature

\section{1. 서 론}

AISI $316 \mathrm{~L}$ 합금은 기존 316 합금에서 $\mathrm{C}$ 함량이 낮아 지고 소량의 $\mathrm{Mo}$ 가 첨가되어 우수한 내식성과 상온 및 고 온에서 높은 기계적 특성을 가지는 소재이다. 이러한 장점 을 바탕으로 이 합금은 파이프, 튜브 등과 같은 일반 구조 용 부품부터 터보 차져, 핵 연료 피복관 등 형상이 복잡하 거나 우수한 고온 기계적 특성이 요구되는 부품으로까지

- 함기수: 박사과정, 박순홍: 책임연구원, 이기안: 교수

${ }^{*}$ Corresponding Author: Kee-Ahn Lee

[Tel: +82-32-860-7532, E-mail: keeahn@inha.ac.kr ]

Copyright $(\mathcal{C})$ The Korean Institute of Metals and Materials
산업 전반에서 널리 사용되고 있다 [1-3]. 또한 316L 합금 은 인공 관절, 임플란트와 같은 생체 재료 산업에서도 주 목받고 있다 [4-6]. 한편 터보 차져, 터빈 블레이드, 생체 부품 등은 그 형상이 복잡하여 일반적인 기존 공정으로 제 조할 경우 매우 높은 단가를 나타내고 있고 이러한 문제점 을 극복할 수 있는 새로운 공정의 도입이 요구되고 있다. 이에 최근 부품 형상 제어의 자유도가 높고 다품종 소량 생 산에서 경제성을 가질 수 있는 금속 3D 프린팅 (metal 3D printing) 공정이 새롭게 적용, 시도되고 있다.

금속 3D 프린팅 공정은 3차원 $\mathrm{CAD}$ (computer aided design)를 이용하여 제품의 형상을 설정하고, 분말(powder) 을 적층 또는 분사하며 열원을 이용하여 용융 시킨 후 
layer by layer 방식으로 적층하여 부품을 생산하는 공정이 다 [7-9]. 전통적인 금속 제조 공정의 경우 일반적으로 주 조, 압연, 단조를 수행하고 이후 절단, 절삭, 표면처리 등 후 가공 공정도 요구된다. 이에 공정 과정 중 재료 손실 (material loss)이 발생하고 가공 기술에 따라 제품 형상의 제한이 크다. 또한 전통적인 공정의 경우 새로운 하나의 부품 생산이 결정된 후 완성 부품까지의 제조 시간이 오래 걸린다는 단점도 가지고 있다. 이에 반해 금속 $3 \mathrm{D}$ 프린팅 공정은 제품을 직접 프린팅하여 사용 가능하며, 필요 시 간단한 후처리 후 바로 부품으로 적용 가능하다. 현재까지 제시된 금속 $3 \mathrm{D}$ 프린팅의 대표적 공정으로는 고출력의 레 이저를 이용하여 금속 분말을 분사와 동시에 녹여 적층시 키는 $\mathrm{DED}$ (direct energy deposition) 방식과 도포된 금속 분말에 선택적으로 고출력 레이저를 조사하여 부분적으로 용융, 적층시키는 $\mathrm{PBF}$ (powder bed fusion) 방식의 두 가 지 종류가 있다 [10]. 일반적으로 $\mathrm{PBF}$ 방식은 $\mathrm{DED}$ 방식 보다 요구 공정 시간은 길지만 치수 정확성이 높고 표면 조도 특성이 우수하며 균일한 미세조직을 얻을 수 있다는 장점을 가지고 있다.

$\mathrm{PBF}$ 방식 중 대표적인 공정인 selective laser melting (SLM) 공정으로 제조된 AISI $316 \mathrm{~L}$ 합금과 관련하여 최근 까지 SLM 공정 조건별 소재 형상 제조 및 내부 결함 특성 이 주로 보고되고 있으며, 적층되는 분말 사이의 binding 기 구에 대해서도 제시된 바 있다 [11-13]. 또한 SLM 공정 변 수들을 변화시켜 미세조직을 제어하는 연구도 진행된 바 있 다 $[13,14]$. 한편 SLM 공정으로 제조된 AISI $316 \mathrm{~L}$ 합금의 구조용 부품으로서 적용 가능성을 확인하기 위해서는 기계 적 특성에 대한 연구가 필수적이나 아직까지 부족한 실정이 다. 관련하여 최근까지 SLM AISI 316L 합금의 인장 특성 과 일부 피로 특성들에 대한 연구가 활발하게 보고되고 있 으나[15-19], 대부분 상온 기계적 특성에 대한 결과들이 주 를 이루고 있으며 고온 환경에서도 사용되는 합금임에도 불 구하고 SLM AISI 316L 합금의 고온 기계적 특성 및 후 열처리의 영향에 대한 것은 제시된 바 없다.

본 연구에서는 SLM 공정으로 AISI 316L 합금을 제조하 고 미세조직 및 상.고온 압축 특성을 조사하였으며 상기 특 성들에 미치는 stress relieving 열처리의 영향에 대해서도 알아보고자 하였다. 이와 함께 SLM AISI 316L 합금의 고 온 변형 기구를 미세조직과 연계하여 토의하고자 하였다.

\section{2. 실험 방법}

본 연구에서는 $\mathrm{EOS}$ 사의 장비와 분말(입도분포 :

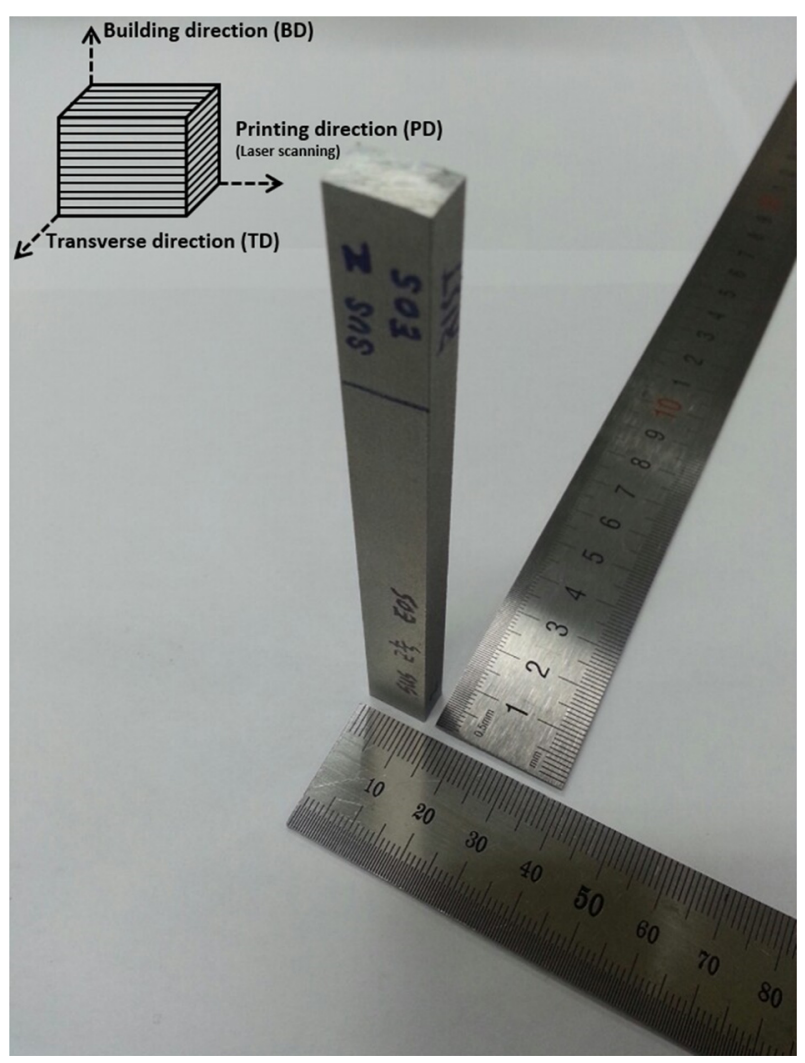

Fig. 1. Image showing initial (as-fabricated) specimen of SLMed AISI $316 \mathrm{~L}$ alloy.

20 50 $\mu \mathrm{m}$, 평균크기 : $37.4 \mu \mathrm{m}$ 의 구형분말)을 사용하여 selective laser melting 공정으로 AISI $316 \mathrm{~L}$ 합금을 제조 하였다. 제조된 시편의 마크로 사진을 그림 1 에 나타내었 다. SLM AISI 316L 소재는 가로 $12 \mathrm{~mm}$, 세로 $7 \mathrm{~mm}$, 높이 $106 \mathrm{~mm}$ 의 크기의 바(bar) 형상으로 제조되었다. 제조 된 $316 \mathrm{~L}$ 합금에서 응력 제거(stress relieving) 열처리의 영향을 알아보기 위해 $650{ }^{\circ} \mathrm{C}$ 에서 1 시간 아르곤 분위기에 서 열처리하였다. 이제부터 열처리 전 합금을 $\mathrm{F}$ 합금, 열 처리 후 합금을 $\mathrm{H}$ 합금으로 표기하고자 한다. 소재의 성 분 분석을 위해 ICP (inductively coupled plasma) 분석 을 수행하였으며, 그 결과를 표 1에 나타내었다. ICP 분석 결과, $\mathrm{Fe}$ 기반에 $\mathrm{Cr}$ 이 $17.3 \mathrm{wt} \%, \mathrm{Ni}$ 이 $14.2 \mathrm{wt} \%$ 첨가 되었고 $2.3 \mathrm{wt} \%$ 의 $\mathrm{Mo}$ 가 포함된 것으로 확인되어 $\mathrm{AISI}$ $316 \mathrm{~L}$ 의 표준 조성에 준하는 것으로 나타났다.

미세조직 관찰을 위해 마운팅(mounting)된 시편의 표면 을 \#2000번까지 $\mathrm{SiC}$ 연마지를 이용하여 연마하였으며 그 후 $1 \mu \mathrm{m}$ 수준으로 다시 미세 연마하였다. 이후 $\mathrm{HCl}$ $30 \mathrm{ml}+\mathrm{HNO}_{3} 10 \mathrm{ml}+$ 증류수 $20 \mathrm{ml}$ 용액을 이용하여 수 초간 에칭하였다. 상분석 및 미세조직 관찰을 위해 $\mathrm{X}-$ 
Table 1. Chemical compositions of SLMed AISI 316L alloy used in this study.

\begin{tabular}{ccccccccc}
\hline wt $\%$ & $\mathrm{C}$ & $\mathrm{Si}$ & $\mathrm{P}$ & $\mathrm{Cr}$ & $\mathrm{Ni}$ & $\mathrm{Mn}$ & $\mathrm{Mo}$ & $\mathrm{Fe}$ \\
\hline Standard AISI 316L & 0.03 & 0.75 & 0.045 & $16.00 \sim 18.00$ & 2.00 & $10.00 \sim 14.00$ & $2.00 \sim 3.00$ & Bal. \\
SLMed AISI 316L & 0.005 & 0.29 & 0.001 & 17.33 & 1.43 & 14.26 & 2.32 & Bal. \\
\hline
\end{tabular}

ray 회절 분석 $(\mathrm{XRD}$, Ultima $\mathrm{IV}, \mathrm{Cu} \mathrm{K} \alpha$, scan step size : $0.05^{\circ}$, scan rate : $\left.2 \% \mathrm{~min}\right)$ 을 수행하였으며, 추가적으로 FE-SEM(field emission scanning electron microscope, Tescan, MIRA 3)과 EBSD(electron back scatter diffraction)를 이용하여 SLM AISI 316L 소재의 미세조직 을 분석하였다.

제조된 SLM AISI $316 \mathrm{~L}$ 소재들의 기계적 특성을 평가 하기 위해 경도 시험과 온도 별 압축 시험을 수행하였다. 경도 시험은 마이크로 비커스 경도계를 사용하여 $300 \mathrm{~g}$ 의 하중으로 총 12 회 측정하였고, 최대, 최소값을 제외한 평 균값을 사용하였다. 압축 시험은 직경 : $4 \mathrm{~mm}$, 높이 : $6 \mathrm{~mm}$ 의 봉상의 시편을 가공하여 사용하였다. 압축 시험 전, 표면 거칠기의 영항을 줄이기 위해 표면을 $\mathrm{SiC}$ 연마지 로 \#2000번까지 연마하였다. INSTRON 8801을 사용하여 상온 및 고온 압축 시험을 수행하였다. 이때 변형율 속도 는 $1 \times 10^{-3} / \mathrm{s}$ 로 설정하였으며, 실험 온도는 상온, $500{ }^{\circ} \mathrm{C}$, $700{ }^{\circ} \mathrm{C}, 900{ }^{\circ} \mathrm{C}$ 총 4 조건에서 수행하였다. 압축 시험은 조건 별로 3 회 수행하였다. 압축 시험 후 초기 미세조직이 압축 특성에 미치는 영향을 조사하기 위해 FE-SEM을 사 용하여 추가로 압축 시편의 표면 및 단면을 관찰하였다.

\section{3. 결과 및 고찰}

\subsection{SLM AISI 316L 합금의 열처리에 따른 미세조직}

그림 2는 SLM AISI $316 \mathrm{~L}$ 소재들 $(\mathrm{F}$ 합금과 $\mathrm{H}$ 합금) 의 단면 미세조직을 관찰한 결과이다. SLM AISI 316L 합금에서는 레이저 열원 방향으로 방향성을 가지고 발달한 조직이 관찰되었으며, 용융 풀(molten pool)의 존재도 확연 히 나타났다. 용융 풀은 SLM 공정 중 레이저 열원의 이 동에 의해 분말들이 용융되면서 생성되는 것으로 알려져 있으며[7], 금속 $3 \mathrm{D}$ 프린팅 소재의 독특한 미세조직적 특 징으로 보고되고 있다. 열처리를 수행한 $\mathrm{H}$ 합금 역시 $\mathrm{F}$ 합금과 큰 차이 없이 유사한 미세조직(용융 풀의 존재와 레 이저 열원 방향으로의 방향성을 가진 조직)을 나타내었다. 용융 풀의 크기는 SLM AISI 316L F 합금 : $198.1 \mu \mathrm{m}$, $\mathrm{H}$ 합금 : $197.7 \mu \mathrm{m}$ 로 유사하게 측정되었다. 한편 금속 $3 \mathrm{D}$ 프린팅 공정으로 제조된 소재의 경우 작은 기공이나 수축공도 생성될 수 있어 제조된 소재의 기공도도 및 기공

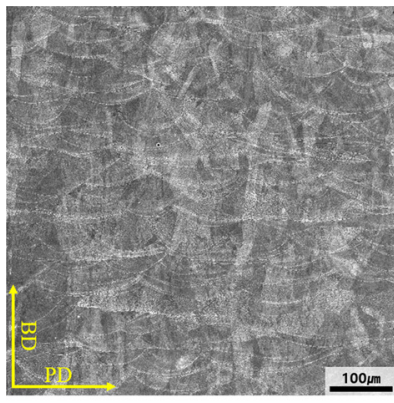

(a)

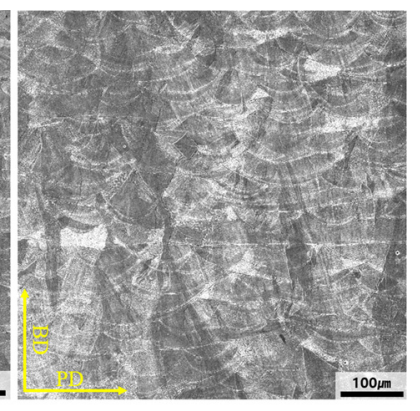

(b)
Fig. 2. Microstructures of SLMed AISI 316L alloys; (a) as fabricated (F) and (b) Heat treated (H).

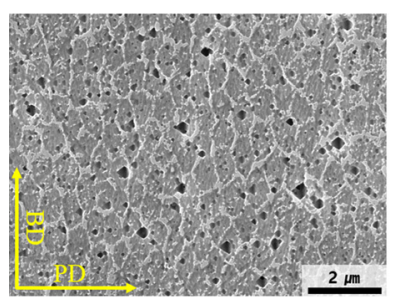

(a)

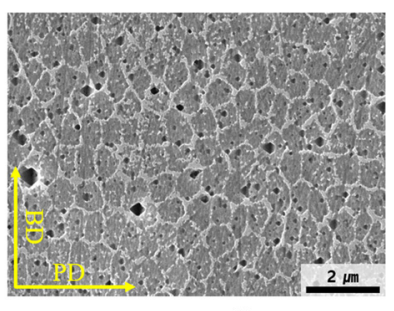

(b)
Fig. 3. High magnification microstructures of SLMed AISI 316L alloys; (a) as fabricated (F) and (b) Heat treated (H).

의 크기는 중요한 미세조직학적 특성들이다. 이미지 분석 기(Image analyzer)를 이용하여 분석한 SLM AISI 316L $\mathrm{F}$ 소재의 기공도는 $0.020 \%, \mathrm{H}$ 소재의 기공도는 $0.018 \%$ 로 나타나 두 소재 모두 매우 치밀한 조직을 가지고 있는 것으로 확인되었다. 또한 $\mathrm{F}$ 합금의 기공의 크기는 평균 $7.8 \mu \mathrm{m}$ 로 측정되었으며 $\mathrm{H}$ 합금은 평균 $7.7 \mu \mathrm{m}$ 의 기공들이 존재하는 것으로 나타나 큰 차이를 보이지 않았다.

SLM AISI 316L F 합금과 $\mathrm{H}$ 합금의 용융 풀 내부 미 세조직을 보다 명확히 관찰하기 위하여 의도적으로 과 에 칭하였으며 그 관찰 결과를 그림 3 에 나타내었다. $\mathrm{F}$ 합금 과 $\mathrm{H}$ 합금 모두 용융 풀 내부에 cellular 타입의 dendrite 가 관찰되었다. 그러나 cellular dendrite의 크기는 F 합금 : $0.64 \mu \mathrm{m}, \mathrm{H}$ 합금 : $0.71 \mu \mathrm{m}$ 로 측정되어 열처리에 따 라 큰 변화를 나타내지 않았다. 이러한 cellular dendrite는 selective laser melting 공정의 빠른 냉각 속도 $\left(10^{3}\right.$ $10^{8} \mathrm{~K} / \mathrm{s}$ )에 기인하여 생성될 수 있다고 보고되고 있다 [20]. 일반적인 냉간 압연-어닐링 소재와 열간 압연 공정으로 제 조된 AISI $316 \mathrm{~L}$ 소재의 결정립 크기가 $17.5 \mu \mathrm{m}$ 


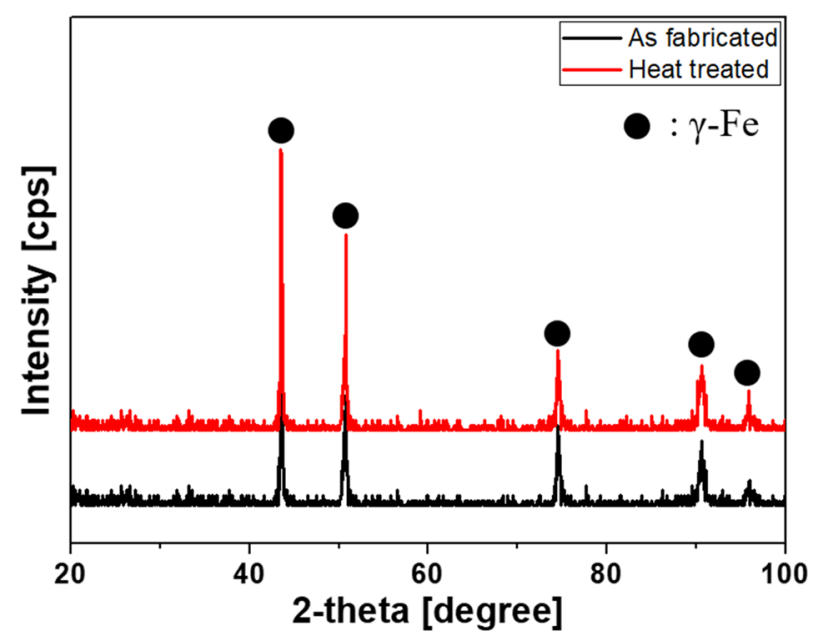

Fig. 4. X-ray diffraction analysis results of SLMed AISI $316 \mathrm{~F}$ and $\mathrm{H}$ alloys.

$148.8 \mu \mathrm{m}$ 로 알려진 것과 비교해 볼 때[21-23], SLM AISI $316 \mathrm{~L}$ 합금은 열처리 유무에 관계없이 매우 미세한 조직으 로 구성되어 있었다.

그림 4는 SLM AISI $316 \mathrm{~L} \mathrm{~F}$ 와 $\mathrm{H}$ 두 합금들의 XRD 상 분석 결과이다. 두 소재 모두 $\gamma-\mathrm{Fe}$ 단상으로 구성되어 있는 것으로 나타났다. 열처리를 수행하여도 추가적인 상
변화는 나타나지 않았으나 XRD 피크가 조금 더 날카롭게 변하고 그 위치도 미소하게 움직인 것으로 나타났다. 금속 $3 \mathrm{D}$ 프린팅 소재의 경우 일반적으로 빠른 냉각 속도에 기 인한 잔류 응력이 소재 내부에 존재하며(as-fabricated) 열 처리를 수행함에 따라 이러한 잔류 응력이 다소 해소될 수 있다. 상기 열처리에 따른 소재 내부의 잔류 응력 변화에 의해 XRD 피크의 차이(그림 4)가 나타난 것으로 생각된다. 열처리에 따른 미세조직적 차이를 보다 명확히 확인하기 위해 $\mathrm{EBSD}$ 분석을 수행하였으며, 그 결과를 그림 5에 도 시하였다. SLM AISI 316L F 와 H 합금들 모두 레이저 열원 방향(적층 방향, building direction)으로 미세조직이 성장, 발달한 것으로 나타났으며 그 외 거시적인 미세조직 의 변화는 확인되지 않았다 ((a) 조건별 왼쪽 그림들). 그 러나 kernel average misorientation angle map (KAM) 분석 결과((a) 조건별 오른쪽 그림들)에서 $\mathrm{F}$ 합금은 내부에 높은 분율의 저 경각 경계(low angle boundary, 초록색 선) 가 나타나며 특히 용융 풀 경계로 예상되는 영역에서 많은 수의 전위 집적이 존재하는 것으로 확인되었다. 이에 반해 $\mathrm{H}$ 합금은 저 경각 경계(초록색 선)의 밀도가 $\mathrm{F}$ 합금에 비 해 감소하였으며, 용융 풀 경계에서도 큰 전위의 집적이 관 찰되지 않았다. 이를 정량적으로 분석한 misorientation
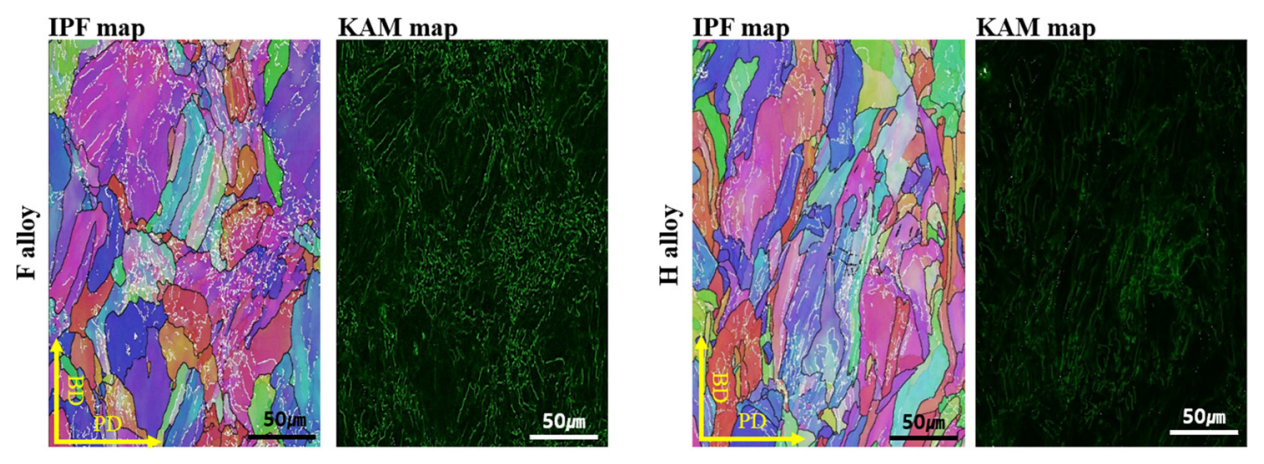

(a)

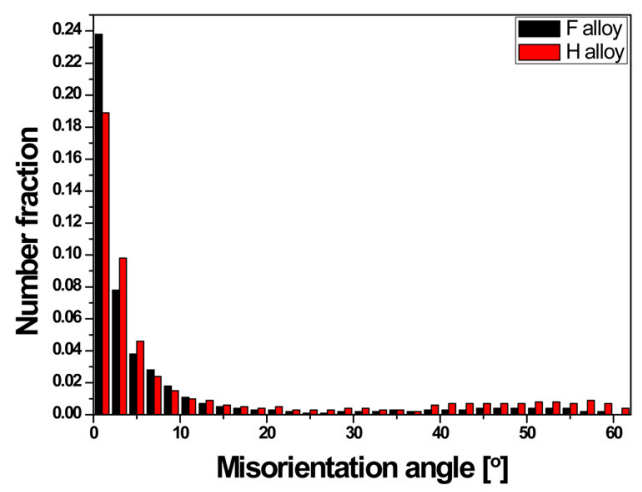

(b)

Fig. 5. EBSD analysis results of SLMed AISI 316L alloys showing (a) IPF and KAM maps, (b) misorientation angle distribution. 
angle distribution 그래프 (b) 에서 열처리를 수행함에 따 라 저 경각 경계 비율이 감소하고 고 경각 경계 (high angle boundary)의 비율이 증가함을 다시 한번 확인할 수 있다. 상기 결과는 응력 제거 열처리를 수행함에 따라 용 융 풀 경계에서 뿐만 아니라 용융 풀 내부에도 존재하던 잔류 응력이 일부 해소되었음을 의미한다.

\subsection{SLM AISI 316L 합금들의 상, 고온 압축 특성} 및 변형 거동

SLM AISI $316 \mathrm{~L}$ 합금의 방향 별 경도 시험을 수행하였 으며, 그 결과를 그림 6 에 나타내었다. $\mathrm{F}$ 합금의 평균 경도 값은 $\mathrm{PD}$ (printing direction) : $222 \mathrm{Hv}, \mathrm{TD}$ (transversal direction) : $219 \mathrm{Hv}, \mathrm{BD}$ (building direction) : $220 \mathrm{Hv}$ 로 측정되었으며, $\mathrm{H}$ 합금의 경우 $\mathrm{PD}$ (printing direction) : 200 Hv, TD(transversal direction) : $201 \mathrm{Hv}$, BD(building direction) : $197 \mathrm{Hv}$ 의 경도 값을 보였다. 즉 열처리를 수 행함에 따라 전반적으로 경도가 18 23 Hv 감소하고 경도 값의 변동폭 또한 감소하였다. 그러나 두 합금 각각에서 방향별로 경도를 비교하였을 때 그 차이는 약 3 4 Hv로

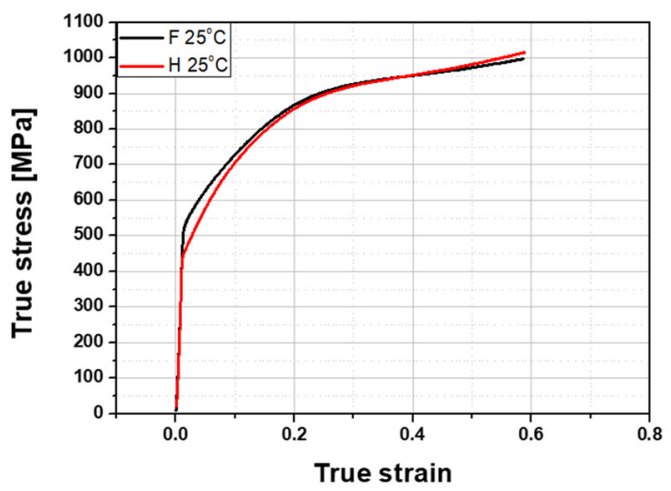

(a)

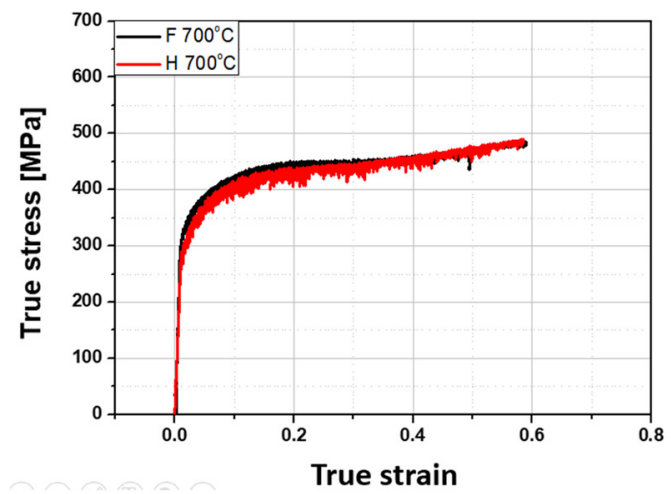

(a)

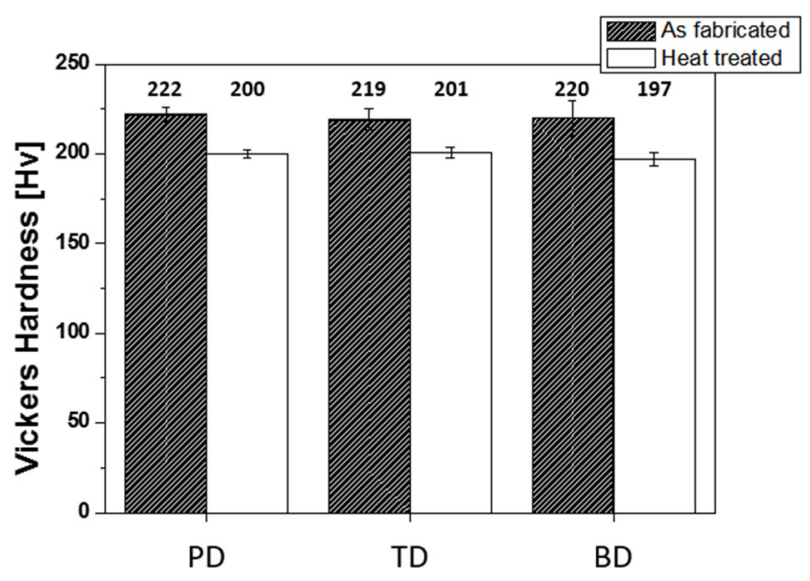

Fig. 6. Vickers hardness results of SLMed AISI 316L F and H alloys.

크지 않았다. 즉 두 합금들 $(\mathrm{F}$ 와 $\mathrm{H})$ 모두에서 방향에 따른 기계적 이방성은 미소하였다.

그림 7에 상온 및 고온 압축 시험으로 얻은 각 합금별 진응력-진변형률(true stress-true strain) 곡선들을 도시하였

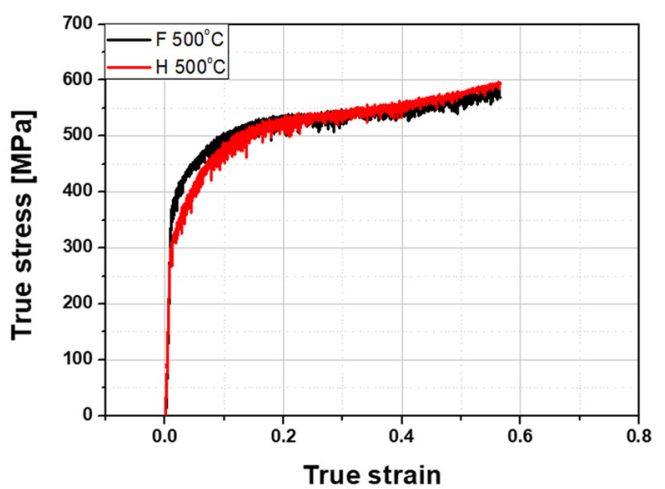

(b)

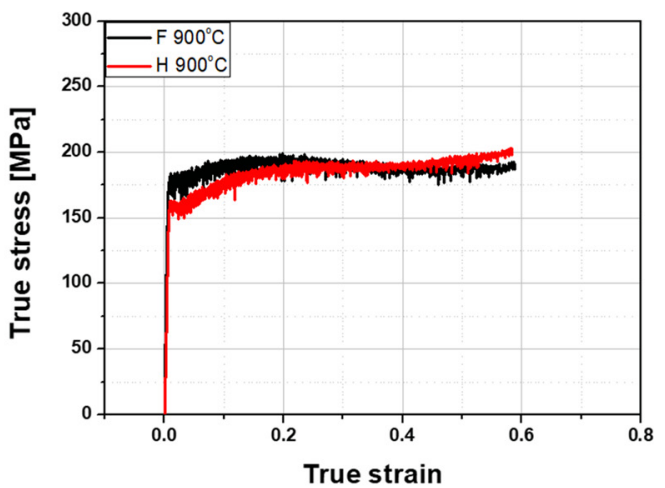

(b)

Fig. 7. True stress vs. true strain curves of SLMed AISI 316L F and $\mathrm{H}$ alloys obtained by compressive tests at (a) room temperature, (b) $500{ }^{\circ} \mathrm{C}$, (c) $700{ }^{\circ} \mathrm{C}$ and (d) $900{ }^{\circ} \mathrm{C}$. 

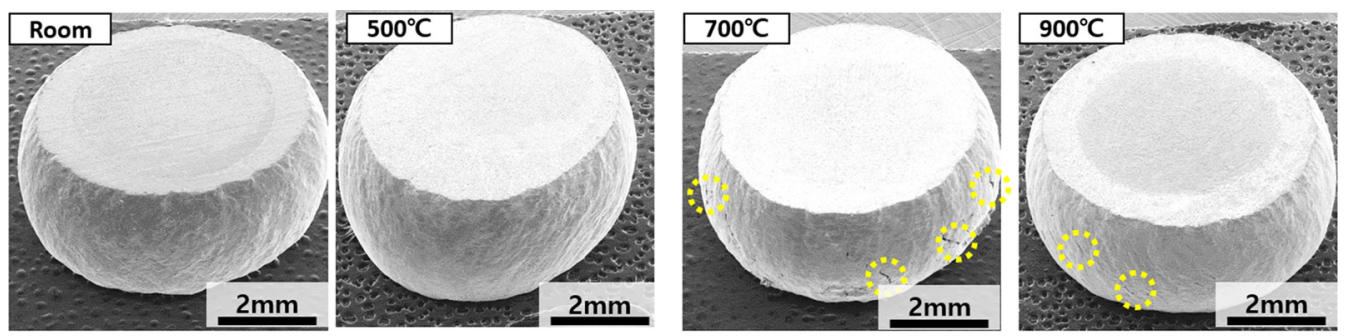

(a)
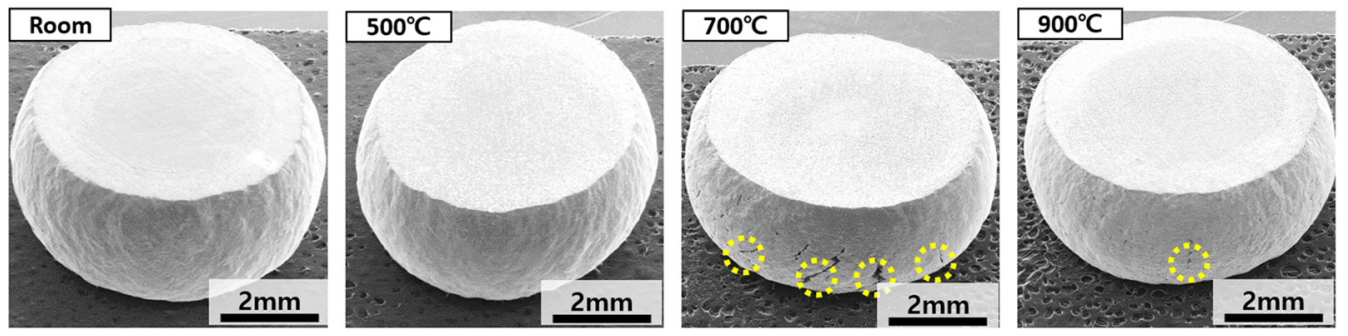

(b)

Fig. 8. Low magnification surface observation results of SLMed AISI 316L alloys after room and elevated temperature compressive tests; (a) F alloy and (b) $\mathrm{H}$ alloy.

다. SLM AISI $316 \mathrm{~L} \mathrm{~F}$ 합금의 항복 강도는 온도별로 상 온 : $536 \mathrm{MPa}, 500{ }^{\circ} \mathrm{C}: 368 \mathrm{MPa}, 700{ }^{\circ} \mathrm{C}: 310 \mathrm{MPa}, 900{ }^{\circ} \mathrm{C}$ : $171 \mathrm{MPa}$ 로 얻어졌다. $\mathrm{H}$ 합금에서는 상온 : $455 \mathrm{MPa}$, $500{ }^{\circ} \mathrm{C}: 338 \mathrm{MPa}, 700{ }^{\circ} \mathrm{C}$ : $301 \mathrm{MPa}, 900{ }^{\circ} \mathrm{C}: 160 \mathrm{MPa}$ 의 항복강도들을 보여 응력완화 열처리를 수행함에 따라 항복 강도가 모든 변형 온도에서 감소하는 것으로 확인되었다. 한편 0.6 진변형률에서 각 소재들 $(\mathrm{F}$ 및 $\mathrm{H}$ 합금들)의 온도 별 최대 응력(peak stress)를 구해보면, SLM AISI 316L F 합금은 상온 : $997 \mathrm{MPa}, 500{ }^{\circ} \mathrm{C}$ : $568 \mathrm{MPa}, 700{ }^{\circ} \mathrm{C}$ : $480 \mathrm{MPa}, 900^{\circ} \mathrm{C}: 191 \mathrm{MPa}$ 로 측정되었고, $\mathrm{H}$ 합금은 상온 : $1014 \mathrm{MPa}, 500{ }^{\circ} \mathrm{C}$ : $592 \mathrm{MPa}, 700^{\circ} \mathrm{C}$ : $490 \mathrm{MPa}, 900{ }^{\circ} \mathrm{C}$ : $202 \mathrm{MPa}$ 의 최대 응력들을 보였다. 즉 모든 변형 온도 조건에서 낮은 항복 강도를 보였던 $\mathrm{H}$ 합금에서 더 높은 최대 응력 $(\varepsilon=0.6)$ 을 나타내었다.

전통적인 공정으로 제조된 압연 후 어닐링된 $316 \mathrm{~L}$ 합금 의 항복 강도는 일반적으로 상온에서 $220 \sim 350 \mathrm{MPa}$ 로 보 고되고 있다 [24]. 이를 본 연구에서 얻어진 항복 강도 결 과와 비교해 보았을 때, $3 \mathrm{D}$ 프린팅 공정으로 제조된 SLM AISI $316 \mathrm{~L}$ 합금은 매우 높은 강도 특성을 지니고 있음을 확인할 수 있었다. 한편 각 온도 별 진변형률-진응 력 곡선들을 면밀히 살펴보면, 상온과 $500{ }^{\circ} \mathrm{C}$ 압축 조건에 서는 항복 이후 $\mathrm{F}$ 와 $\mathrm{H}$ 두 소재 모두 변형률이 증가함에 따라 응력이 상승하는 가공 경화(strain hardening) 현상을 보였으며, 열처리를 수행한 $\mathrm{H}$ 합금이 $\mathrm{F}$ 합금보다 더 큰 가공 경화를 나타내었다. 그러나 SLM AISI $316 \mathrm{~L}$ 합금의
가공 경화는 온도가 상승함에 따라 $\left(700^{\circ} \mathrm{C}\right)$ 큰 폭으로 감 소하며, $900{ }^{\circ} \mathrm{C}$ 에서는 거의 가공 경화를 나타내지 않았다. 이와 관련하여 $700{ }^{\circ} \mathrm{C}$ 와 $900{ }^{\circ} \mathrm{C}$ 변형에서는 $\gamma-\mathrm{Fe}$ 기지의 동적 회복 및 동적 재결정에 의한 연화로 현저한 가공 경 화는 일어나지 않은 것으로 사료된다. 즉 SLM AISI $316 \mathrm{~L} \mathrm{H}$ 합금은 응력 제거 열처리를 수행함에 따라 초기 합금 내부에 존재하는 낮은 전위 밀도로 인해 항복 강도는 낮으나(F 합금보다), 소성 변형 시 전위의 축적이 더 쉬워 지고 이에 따라 높은 가공 경화 거동과 높은 최대 응력 (peak stress)를 나타내는 것으로 이해될 수 있다.

그림 8은 SLM 316L 합금의 온도별 압축 시험 후 압 축 시편을 거시적으로 관찰한 결과들이다. $\mathrm{F}$ 와 $\mathrm{H}$ 두 합 금 모두에서 변형 온도와는 무관하게 응력이 가해짐에 따 라 소성 변형 수용에 의해 시편의 중간 부분이 불룩해지는 barreling 이 나타났다. 이 불룩한 영역을 보다 자세히 관 찰해 보면, 상온과 $500{ }^{\circ} \mathrm{C}$ 의 경우 시편 표면에서 균열이 관찰되지 않았으나, $700{ }^{\circ} \mathrm{C}$ 에서는 조대한 균열들이, $900{ }^{\circ} \mathrm{C}$ 에선 상대적으로 미세한 균열들이 표면에 존재하였다.

이에 압축 표면을 보다 고배율로 관찰한 결과를 변형 온 도별로 그림 9 (상온 및 $500{ }^{\circ} \mathrm{C}$ )와 그림 $10\left(700{ }^{\circ} \mathrm{C}\right.$ 와 $900{ }^{\circ} \mathrm{C}$ )에 각각 나타내었다. 상온에서 $\mathrm{F}$ 합금의 경우 최대 전단 응력 방향으로 희미한 deformation band 가 관찰되었 으며, 응력완화 열처리를 수행한 $\mathrm{H}$ 합금에서 deformation band 가 더 많고 뚜렷하게 관찰되었다(그림 9 (a)). 이러한 경향성은 $500{ }^{\circ} \mathrm{C}$ 의 조건에서 압축을 수행한 합금들에서도 

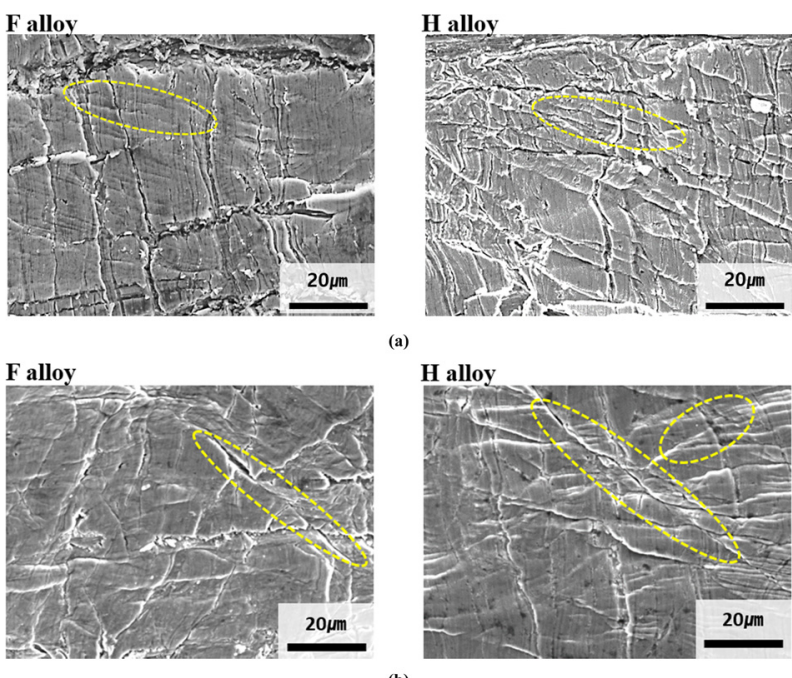

(b)

Fig. 9. FE-SEM observation results of surface fractographies of SLMed AISI 316L F and $\mathrm{H}$ alloys after compression testes at (a) room temperature and (b) $500{ }^{\circ} \mathrm{C}$.

동일하게 확인되었다(그림 9 (b)). 그러나 온도가 증가함에 따라 열처리 유무에 상관없이 deformation band 의 특징 은 약화되었다. $\mathrm{H}$ 합금의 상온 및 $500{ }^{\circ} \mathrm{C}$ 압축 시편 표면 에서 관찰된 상대적으로 ( $\mathrm{F}$ 합금에 비해) 더 발달된 deformation band 들은, 이 변형 온도들에서 확인된 $\mathrm{H}$ 합
금의 높은 가공 경화 거동(그림 7 의 상온과 $500^{\circ} \mathrm{C}$ 응력변형률 곡선)을 설명하는 증거로 해석될 수 있다.

한편 $700^{\circ} \mathrm{C}$ 의 경우(그림 10 (a)), $\mathrm{F}$ 와 $\mathrm{H}$ 합금들 모두 에서 상온과 $500{ }^{\circ} \mathrm{C}$ 변형에서는 관찰되지 않았던 표면 산 화가 나타났으며 이와 함께 조대 균열들도 확연하게 관찰 되었다. 즉 $700^{\circ} \mathrm{C}$ 이상의 고온 압축 시에는 높은 온도에 기인하여 시편의 표면 산화가 진행되고 그 후 변형이 수반 됨에 따라 취약한(brittle) 산화물이 깨짐과 생성이 반복되 며 산화물 탈락 영역에서의 응력 집중으로 인해 조대한 균 열이 생성될 수 있는 것으로 사료된다. 한편 $900{ }^{\circ} \mathrm{C}$ 의 경 우도 열처리 유무에 상관없이 (F와 $\mathrm{H}$ 합금들 모두) 시편 표면에서 표면 산화가 나타났으며 균열들도 함께 관찰되었 으나 앞서 그림 8 에서 언급한 바와 같이 균열의 크기는 $700^{\circ} \mathrm{C}$ 와 비교하여 상대적으로 미세하였다.

그림 $11(\mathrm{a})$ 는 $700^{\circ} \mathrm{C}$ 와 $900^{\circ} \mathrm{C}$ 온도에서 수행한 $\mathrm{F}, \mathrm{H}$ 소재들의 압축 단면 미세조직을 관찰한 결과이다. $700{ }^{\circ} \mathrm{C}$ 소재의 경우 열처리 유무와 관계없이 단면에서도 조대한 균열들이 확인되었으며, 균열 주위에서 미세한 산화물 또 한 관찰되었다. 반면 $900{ }^{\circ} \mathrm{C}$ 에서는 조대한 균열들은 관찰 되지 않았고 변형 조직의 기지 내부에 산화물들이 갇혀 있 는 것으로 나타났다. 그림 11 (b)에는 $700{ }^{\circ} \mathrm{C}$ 와 $900{ }^{\circ} \mathrm{C}$ 온도에서 수행한 $\mathrm{F}, \mathrm{H}$ 소재들의 에칭 후 압축 단면 미세

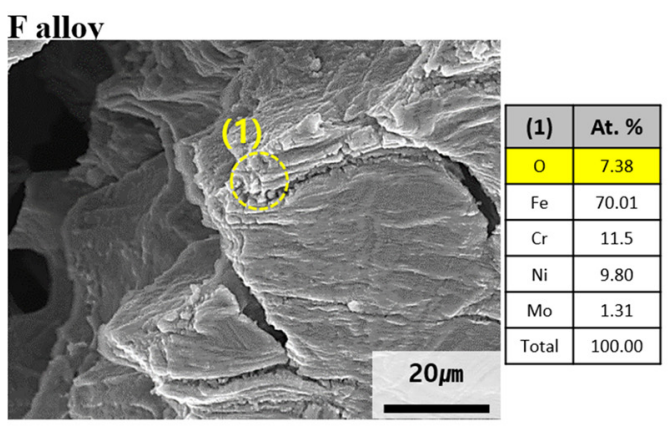

\section{H alloy}

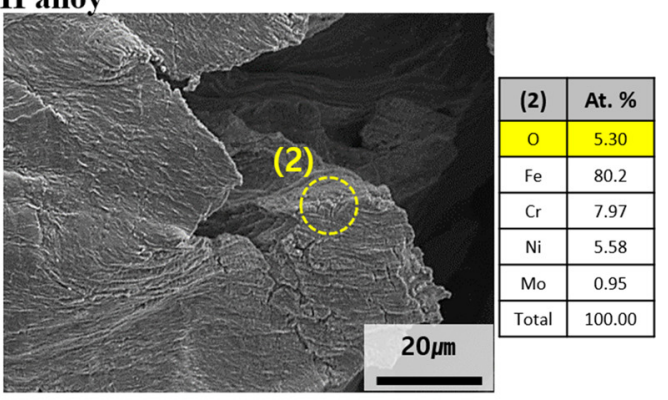

(a)
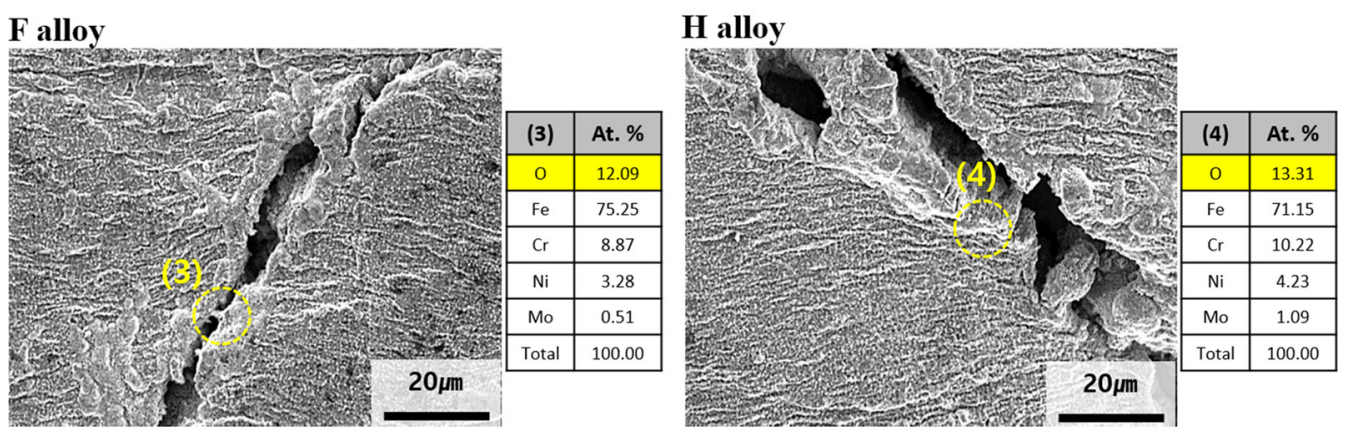

(b)

Fig. 10. FE-SEM observation results of surface fractographies of SLMed AISI $316 \mathrm{~L} \mathrm{~F}$ and $\mathrm{H}$ alloys after compression testes at (a) $700{ }^{\circ} \mathrm{C}$ and (b) $900{ }^{\circ} \mathrm{C}$. 


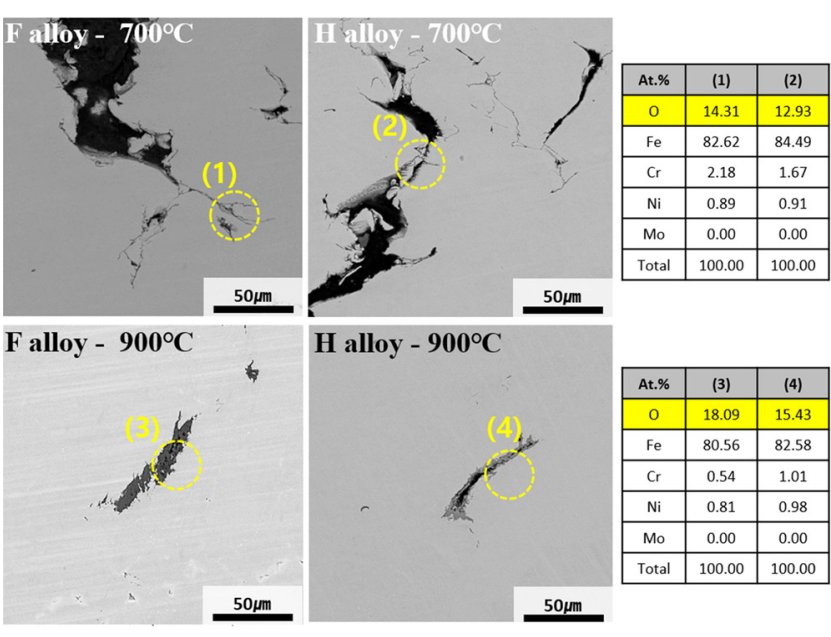

(a)
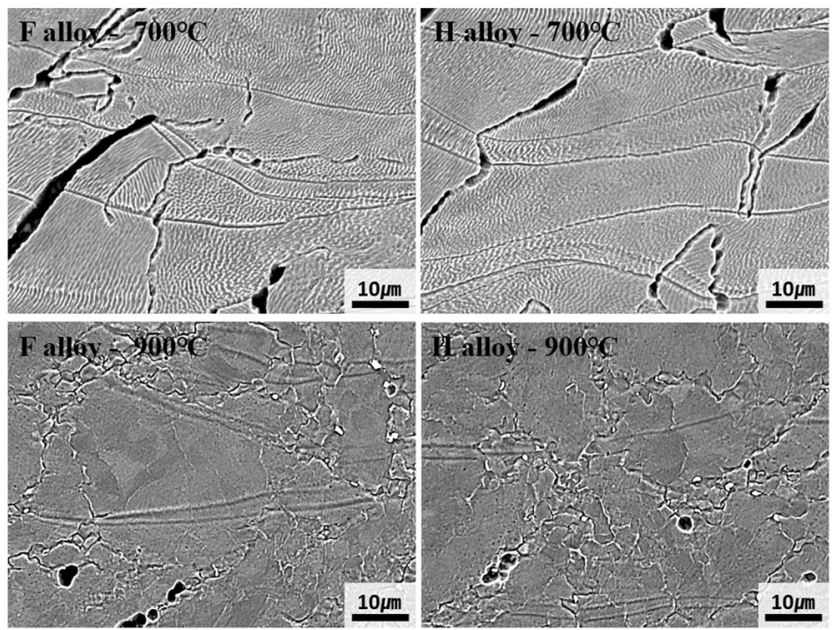

(b)

Fig. 11. cross-sectional observation results of SLMed AISI 316L F and $\mathrm{H}$ alloys after compressive tests at (a) before etching and (b) after etching.

조직을 나타내었다. $700{ }^{\circ} \mathrm{C}$ 에서는 두 소재 모두 초기 미세 조직에서 존재하는 용융 풀과 cellular dendrite가 존재하는 것으로 관찰되었다. $900{ }^{\circ} \mathrm{C}$ 에서는 용융 풀은 관찰되나 앞 선 미세조직에서 관찰된 cellular dendrite는 확인되지 않았 다. 또한 초기 미세조직에서 관찰되지 않았던 약 $8 \sim 10 \mu \mathrm{m}$ 의 결정립들이 생성된 것으로 나타나 $900{ }^{\circ} \mathrm{C}$ 에서 두 소재 모두 동적 회복 및 재결정이 일어난 것으로 판단된다. 즉 $700{ }^{\circ} \mathrm{C}$ 의 경우 동적 회복 및 재결정과 같은 미세조직 변화 의 영향보다 산화의 영향이 커서 변형과 산화가 진행됨에 따라 산화물에서의 응력 집중으로 인해 균열이 내부로 전 파된 것으로 생각된다. 이에 반해 $900{ }^{\circ} \mathrm{C}$ 의 경우 산화의 영향보다 미세조직의 변화의 영향이 더 커서 생성된 산화 물을 고립시키고 파단을 저지하며 이에 상대적으로 $\left(700^{\circ} \mathrm{C}\right.$
에 비해) 더 미세한 균열이 생성된 것으로 사료된다.

\section{4. 결 론}

본 연구에서는 금속 $3 \mathrm{D}$ 프린팅 공정 중 하나인 selective laser melting 법을 이용하여 AISI 316L 합금을 제조하였고 제조된 소재의 고온 압축 특성에 대해 조사하 여 다음과 같은 결론을 얻었다.

1. SLM AISI $316 \mathrm{~L}$ 합금은 기공이 거의 없는 매우 치 밀한 미세조직을 가지고 있었다. 또한 레이저 열원 방향으 로 방향성을 가지는 미세조직이 발달하였으며, 분말들의 용 융된 흔적인 용융 풀도 관찰되었다. 용융 풀 내부에는 미 세한 cellular type의 dendrite가 확인되었다. Cellular dendrite의 크기는 $\mathrm{F}$ 합금의 경우 $0.64 \mu \mathrm{m}, \mathrm{H}$ 합금의 경 우 $0.71 \mu \mathrm{m}$ 로 측정되었다. 그러나 열처리를 수행함에 따라 소재 내부의 EBSD local misorientation angle map 분석 에서 저 경각 경계의 비율이 감소하고 고 경각 경계의 비 율이 증가하는 것을 알 수 있었다.

2. F 합금과 $\mathrm{H}$ 합금의 상.고온 압축 시험 결과, $\mathrm{F}$ 소재 의 항복 강도는 상온 : $536.7 \mathrm{MPa}, 500^{\circ} \mathrm{C}: 368.0 \mathrm{MPa}$, $700{ }^{\circ} \mathrm{C}: 310.4 \mathrm{MPa}, 900{ }^{\circ} \mathrm{C}: 171.3 \mathrm{MPa}$ 로 측정되었다. 열 처리를 수행한 $\mathrm{H}$ 합금은 상온 : $455.5 \mathrm{MPa}, 500{ }^{\circ} \mathrm{C}$ : $338.2 \mathrm{MPa}, 700{ }^{\circ} \mathrm{C}: 301.5 \mathrm{MPa}, 900{ }^{\circ} \mathrm{C}: 160.1 \mathrm{MPa}$ 의 항복 강도를 나타내어 열처리를 수행함에 따라 항복 강도 가 소폭 감소하였다. 하지만 각 소재의 온도 별 최대 응력 의 경우, SLM AISI $316 \mathrm{~L} \mathrm{~F}$ 합금은 압축 온도별로 상온 : $997.2 \mathrm{MPa}, 500^{\circ} \mathrm{C}$ : $568.2 \mathrm{MPa}, 700^{\circ} \mathrm{C}: 480.1 \mathrm{MPa}$, $900{ }^{\circ} \mathrm{C}: 191.4 \mathrm{MPa}$ 로 측정되었으며, 열처리를 수행한 $\mathrm{H}$ 합금은 상온 : $1014.9 \mathrm{MPa}, 500{ }^{\circ} \mathrm{C}$ : $592.2 \mathrm{MPa}, 700{ }^{\circ} \mathrm{C}$ : $490.8 \mathrm{MPa}, 900{ }^{\circ} \mathrm{C}: 202.5 \mathrm{MPa}$ 값을 보여, 열처리를 수행한 $\mathrm{H}$ 합금이 오히려 더 높은 최대 응력값을 나타내었 다. 즉 $\mathrm{H}$ 합금에서 더욱 큰 가공 경화 거동을 보였다.

3. 압축 파단 표면 관찰 결과, 상온과 $500{ }^{\circ} \mathrm{C}$ 에서는 두 합금( $\mathrm{F}$ 와 $\mathrm{H}$ 합금) 모두 전단 응력 방향으로 미세한 deformation band가 관찰되었고, 응력완화 열처리를 수행한 $\mathrm{H}$ 합금에서 더 많은 수의 deformation band가 뚜렷하게 확인되었다. 한편 $700{ }^{\circ} \mathrm{C}$ 에서는 조대한 표면 균열이, $900{ }^{\circ} \mathrm{C}$ 에선 미세한 균열이 관찰되었고 시편 표면과 균열 주 위에서 산화물이 검출되었다. 압축 단면 관찰 결과, $700{ }^{\circ} \mathrm{C}$ 의 경우 열처리 유무와 관계없이 조대한 균열들이 존재하 고 있음을 다시 한번 확인 할 수 있었으며, 균열의 경계에 서 미세한 산화물이 관찰되었다. 반면 $900{ }^{\circ} \mathrm{C}$ 에서는 조대한 균열들은 관찰되지 않았고 동적 회복 및 재결정에 의해 시 
편 내부에 산화물들이 갇혀 있는 특징을 나타내었다.

\section{감사의 글}

본 연구는 산업통상자원부의 “첨단 신소재 기반 $3 \mathrm{D}$ 프 린팅 전문인력양성 사업”의 지원으로 수행되었으며 이에 감사드립니다.

\section{REFERENCES}

1. A. K. Gupta, H. N. Krishnamurthy, Y. Singh, K. M. Prasad, and S. K. Singh, Mater. Des. 45, 616 (2013).

2. X. Y. Wang and D. Y. Li, Wear 255, 836 (2003).

3. V. Karthik, S. Murugan, P. Parameswaran, C. N. Venkiteswaran, K. A. Gopal, N. G. Muralidharan, S. Saroja, and K. V. kasiviswanathan, Energy Proced. 99, 35 (2016).

4. S. K. Samanta, S. K. Mitra, and T. K. Pal, Mater. Sci. Eng. A 430, 242 (2006).

5. T. Hryniewicz, R. Rokicki, and K. Rokosz, Suf. Coat. Technol. 202, 1668 (2008).

6. E. Paffumi, K. F. Nilsson, and N. G. Taylor, Int. J. Pres. Ves. Pip. 85, 798 (2008).

7. J. P. Kruth, L. Froyen, J. V. Vaerenbergh, P. Mercelis, M. Rombouts, and B. Lauwers, J. Mat. Proc. Tech. 149, 616 (2004).

8. L. Thijs, F. Verhaeghe, T. Craeghs, J. V. Humbeeck, and J. P. Kruth, Acta Mater. 58, 3303 (2010).

9. B. Vandenbroucke and J. P. Kruth, Rap. Proto. J. 13, 196 (2007).
10. D. Herzog, V. Seyda, E. Wycisk, and C. Emmelmann, Acta Mater. 117, 371 (2016).

11. I. Tolosa, F. Garciandia, F. Zubiri, F. Zapirain, and A. Esnaola, Int. J. Adv. Manuf. Technol. 51, 639 (2010).

12. R. Li, Y. Shi. Z. Wang, L. Wang, J. Liu, and W. Jiang, App. Surf. Sci. 256, 4350 (2010).

13. B. Zhang, L. Dembinski, and C. Coddet, Mater. Sci. Eng. A 584, 21 (2013).

14. I. Yadroitsev, P. Krakhmalev, I. Yadroitsava, S. Johansson, and I. Smurov, J. Mat. Proc. Tech. 213, 606 (2013).

15. M. Sergio, F. Lima, and S. Sankare, Mater. Des. 55, 526 (2014).

16. W. Shifeng, L. Shuai, W. Qingsong, C. Yan, Z. Sheng, and S. Yusheng, J. Mat. Proc. Tech. 214, 2660 (2014).

17. B. Song. S. Dong. Q. Liu, H. Liao, and C. Coddet, Mater. Des. 43, 727 (2014).

18. P. Mercelis and J. P. Kruth, Rap. Proto. J. 12, 254 (2006).

19. A. Riemer, S. Leuders, M. Thone, H. A. Richard, T. Troster, and T. Niendorf, Eng. Fract. Mech. 120, 15 (2014)

20. L. Liu, Q. Ding, Y. Zhong, J. Zou, J. Wu, Y. L. Chiu, J. Li, Z. Zhang, Q. Yu, and Z. Shen, Mater. Today 21, 354 (2018).

21. W. A. Poling, MS thesis, Colorado school of Mines, Colorado (2012).

22. J. S. Kim, J. N. Kim, and C. Y. Kang, Korean J. Met. Mater. 56, 265 (2018).

23. Z. N. Li, F. A. Wei, P. Q. La, and F. L. Ma, Met. Mater. Int. 24, 633 (2018).

24. J. Y. Huang, J. J. Yeh, S. L. Jeng, C. Y. Chen, and R. C. Kuo, Mater. Trans. 47, 409 (2006). 